\title{
Extractives and Sustainable Community Development: A Comparative Study of Women's Livelihood Assets in the Americas
}

\author{
Isabel B. Franco ${ }^{1} \&$ Titi Kunkel ${ }^{2}$ \\ ${ }^{1}$ Postdoctoral Research Fellow, Institute for the Advance Study of Sustainability, United Nations University \\ ${ }^{2}$ MBA, MNRES, PhD, Acting Regional Chair South-Central, Adjunct Professor, First Nations Studies, University of \\ Northern British Columbia, Canada \\ Correspondence: Titi Kunkel, MBA, MNRES, PhD, Acting Regional Chair South-Central, Adjunct Professor First \\ Nations Studies, University of Northern British Columbia, Canada. \\ Isabel B. Franco, Ph.D, Postdoctoral Research Fellow, Institute for the Advance Study of Sustainability, United Nations \\ University, Japan.
}

\author{
Received: August 3, 2017 \\ Accepted: August 30, $2017 \quad$ Available online: October 23, 2017 \\ doi:10.11114/ijsss.v5i11.2724 \\ URL: https://doi.org/10.11114/ijsss.v5i11.2724
}

\begin{abstract}
The world has experienced a rapid growth in the mining industry due to increased demand for minerals. However, this situation has given rise to complexities in resource regions, compromising how women sustain their livelihoods. With increasing deregulation and globalization of the world economy, the livelihoods of women in resource-rich regions deserve special attention. Women in communities adjacent to extractive operations commonly experience a loss of livelihood options. Using case studies, this paper compares the livelihoods of women in two resource regions, Risaralda in Colombia and an Indigenous community in Nemiah Valley of British Columbia in Canada. This paper argues that the extractive industry should engage with women to enhance their assets and help them forge more sustainable livelihood options. The paper also makes recommendations to stakeholders on how livelihood as sets can be enhanced to benefit women in resource development regions.
\end{abstract}

Keywords: sustainable livelihoods, women, indigenous communities, extractive industry, community development

\section{Introduction}

The world has experienced a rapid growth in the extractive industry due to increased demand for natural resources. The total net output of the mining sector in the world grew by $1.7 \%$ in 2013 (United Nations Industrial Development Organization, 2014). With increasing deregulation and globalization of the world economy, the mining sector has experienced significant growth. This growth has given rise to complexities such as the livelihood options for women in resource-rich regions. Studies show that women who live in communities adjacent to extractive operations are adversely impacted by mine development and have fewer livelihood options (Bashwira, Cuvelier, \& Hilhorst, 2013; Jenkins, 2014; see Lahiri-Dutt, 2013; O'Faircheallaigh, 2013). With the recognition that resources such as minerals and metals are non-renewable and the extraction is finite, it is necessary for industry actors to engage with women who live adjacent to extractive operations, to fashion sustainable livelihoods in these resource-rich regions (Franco, 2014; Kunkel, 2014). Using case studies from Risaralda, Colombia and the Indigenous ${ }^{1}$ Tsilhqot'in people in British Columbia, this paper argues that the extractive industry should do more to engage in enhancing the livelihood options and economic assets for women in resource-rich regions. This paper makes recommendations and shares some best practices that can be applied to other resource regions.

\subsection{Sustainable Development and Women}

World leaders at the United Nations Millennium Summit of September 2000 recognized the need to promote gender equality and to empowerment women as a way to stimulate sustainable development and to effectively combat poverty, hunger, and diseases (United Nations, 2000). Reports show that women are disadvantaged in securing paid jobs and face

\footnotetext{
${ }^{1}$ Canada's Indigenous people consist of First Nations, Inuit, and Metis people. These Indigenous groups are commonly referred to as Aboriginal people.
} 
inequality in income, experience higher unemployment rates, and are disproportionately represented in the informal and subsistence sectors (Foro Internacional de Mujeres Indigenas, 2006; Roy, 2004; United Nations Development Program, 2006). The identified major causes of this inequality included sociocultural attitudes, employment policies, and the lack of options for balancing work and family responsibilities or for controlling the timing and spacing of births (United Nations Development Program, 2006, p. 8). Creating sustainable livelihoods for women is important and was deemed as a way forward in resource development regions. Concepts such as sustainable livelihoods abound in the present day Sustainable Development (SD) literature (see Krantz, 2001; Lahiri-Dutt, 2013). While the notion of SD owes its origins to environmental activists in the 19th century, in the contemporary era, this is viewed as a broad term encompassing a wide range of social, economic, environmental and political elements (Dresner, 2008, p. 19). Global organizations such as the World Bank and the United Nations have embraced the Brundtland Commission's definition of SD as "meet(ing) the needs of the present without compromising the ability of future generations to meet their own needs" (World Commission on Environment and Development 1987,31). The Commission's definition was based on an anthropocentric perspective that places humans at the centre while downplaying other important components such as the environment itself. This SD approach had made way for a proliferation of global and local agendas pertinent to development, for example, the Sustainable Livelihood Framework (SLF) that had gained popularity with de velopment agencies (Krantz, 2001). Studies showed that Indigenous people whose communities or lands were at close proximity to extractive locations were often marginalized and unable to participate equally in development opportunities (Buitrago Franco, 2013; Kunkel 2013, 2014, \& 2017). The concept of SD encompasses developments that ensure the survival cultures and meet the needs of the people for seven generations to come (Clarkson, Morisette, \& Regallet, 1992; Kunkel , 2008). Scholars call for the creation of social enterprises on Indigenous lands as these have the benefits of delivering a quadruple bottom line, namely financial, social, cultural, and environmental performance targets which they believe are required for sustainability and the social development of these communities (Wallace, 1999; Anderson, Dana, \& Dana, 2006; Peredo \& Chrisman, 2006; Raha et al, 2013; Said-Allsopp \& Tallontire 2015).

\subsection{Sustainable Livelihoods}

Following the anthropocentric approach to SD, the notion of sustainable livelihoods was conceived as a way of thinking about the objectives, scope, and priority of development (Carney, 2003, pp. 14-15; Rakodi \& Lloyd-Jones, 2002). In 1998, the British Government's Department for International Development (DFID) adopted the SLF as an approach to assessing and e valuating de velopmental projects that the organization funded. Since then several other international organizations, like the United Nations Development Program (UNDP) and the Non-Government Organization (NGO) CARE International have adopted the SLF as an approach with which to carry out their projects (Carney, 2003, p. 11; Krantz, 2001). One of the core components of SLF, relevant to this research, is the notion of 'livelihood' itself. According to DFID $(1999,1)$, a livelihood encompasses the capabilities and activities required for making a living. This was stated as "sustainable when it can cope with and recover from stresses and shocks and maintain or enhance its capabilities and assets both now and in the future" (DFID 1999, 1). Notwithstanding the use of SLF by many organizations, a major criticism is that its application fails to provide an adequate role for the private sector (Carney, 2003; Franco, 2014). Thus, the first case study in this paper examines how some extractive industries participate in creating sustainable livelihoods for women. Forging sustainable livelihoods necessitates placing people, particularly women, at the centre of SD agendas. This approach has the potential to overcome community development limitations often caused by reliance of the people on locally available natural resources (Kunkel, 2014; Franco, 2017). The second case study in this paper examines how women maintain their livelihoods through their dependence on the lands.

\section{Research Design and Case Studies}

The case studies described in this paper used qualitative methods and approaches in two very diverse resource-rich regions, Risaralda in Colombia, and the Nemiah Valley of British Columbia, Canada. The case described comprise of two independent studies - the Risaralda women in Colombia and the Tsilhqot'in women in Canada. The selection of the locations were based on three criteria: 1) the region must be resource-rich;2) there are evidence of limited or no essential infrastructure and assets required by women to achieve their full potentials; and 3) the region must display complexities and opportunities in forging sustainable livelihoods for women.

The Risaralda case study involved the combination of methods and techniques, thus reducing any bias and limitations derived from the application of single method (Singleton \& Straits, 2010). Using case study as the basic methodological approach, the analysis incorporated a literature review, policy document analysis, stakeholder analysis, face-to-face semi-structured interviews, and group interviews.

Group interviews were conducted with key civil organization leaders from non-extractive industries. Participants include people who were engaged in jewellery making and agriculture. In addition, some participants were engaged in community capacity-building building initiatives in the case study area. Data collected from community leaders in the mining 
industry were used to map and explore capacity-building initiatives and their implications for community members. Similarly, data collected from focus group discussions with senior corporate and go vernment representatives were used to evaluate the roles of stakeholders and forms of collaboration for generating sustainable livelihoods for women in the case study areas.

The Tsilhqot'in case study used qualitative methods and techniques that incorporated content analysis of a lands claim court case document and the transcripts from two environmental assessment (EA) panel hearings of a mine proposal. The court case documents contained oral testimonies from Indigenous ${ }^{1}$ Tsilhqot'in elders and community members along with reports from professionals such as anthropologist, ethno-botanist, government, corporate representatives and other scientists. Indigenous knowledge and evidence presented in court spanned over 150 years. QSR Nvivo9 was used in processing and categorizing themes as they emerged in the data. These themes were further explored in participant observation at community events and the semi-structured, in-depth interviews conducted with women and leaders from the Xeni Gwet'in community. The final categories were established in a deductive fashion according to the responses of the participants. The data provided a rich description and context for the application of grounded theory. The participant observation and semi-structured interviews provided opportunities to triangulate and to validate data.

\subsection{Risaralda Region, Colombia}

Risaralda is a developing resource region located in the Colombian Andes mountain range (see Figure 1). This geographical area is one of the most active producers of minerals and metals in Colombia. With the escalation of mining operations, stakeholders in Risaralda had attempted to maximize social benefits from mining and exploration operations. Governments, the extractive industry, and civil society had combined their efforts to enhance economic assets for women in order to tackle key community issues. This process had been characterized by active women engagement. The extractive industry, particularly mining, is part of Risaralda's cultural and political/economic life; however, the recent escalation of mining operations undertaken mainly by international companies had not pre vented women from embarking on initiatives that contributed to forging alternative livelihoods.

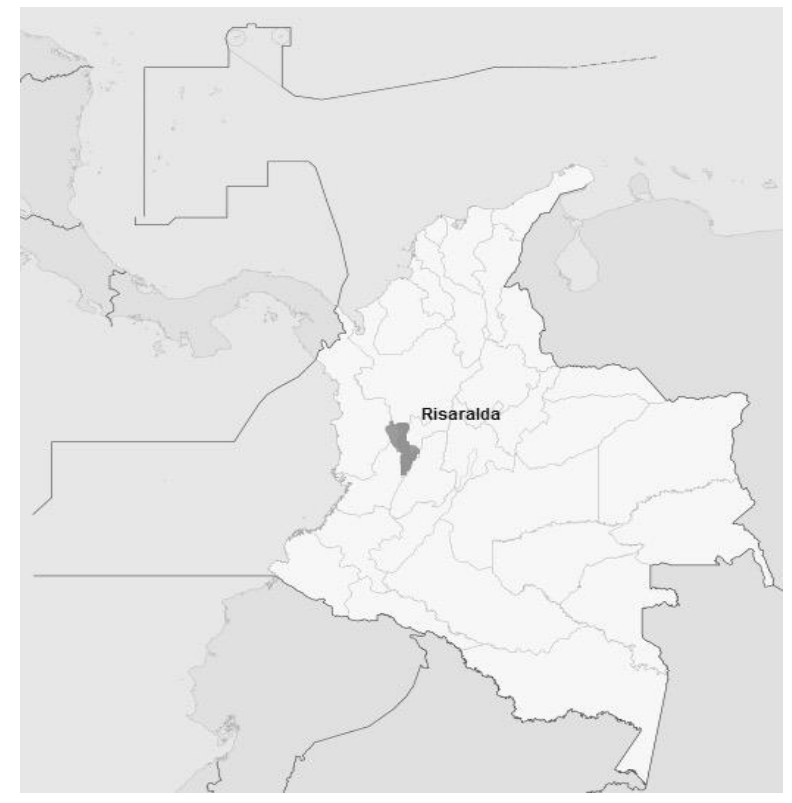

Figure 1. Map of Columbia showing the Risaralda region

Recent increase in mining and exploration projects had become the main driver of economic development in Risaralda. Companies including domestic and Canadian ones were undertaking exploration and mining projects. Mining and exploration activities in Risaralda affect women and their livelihoods, particularly in rural areas. According to the 2005 census $^{2}$, the population of Risaralda was 194,562 people in the urban fringe and rural areas. The average per household was 3.6 people (Departamento Administrativo Nacional de Estadísticas, 2005). The census showed that $51.3 \%$ of the population were female and literacy levels were low with $40.3 \%$ of the population completing elementary school (Departamento Administrativo Nacional de Estadísticas, 2005). The average of working population was 81.8\% in 2012. Data also shows that $54.9 \%$ of the population was employed. Regarding unemployed population, $42.6 \%$ were women and $67.8 \%$ were men, indicating that women have become more resilient to mining impacts and have been able to sustain their

\footnotetext{
${ }^{2}$ Risaralda's last census took place in 2005. The next one is due in 2018 .
} 
livelihoods despite increasing extractive activities (See Table 1).

Table 1. Risaralda Community Profile, 2008 Census

\begin{tabular}{lc}
\hline Risaralda Indicator & Data \\
\hline Population living in the urban fringe and rural areas & 194,562 \\
Average of people per household & 3.6 \\
Female population & $51.3 \%$ \\
Population enrolled in elementary school & $40.3 \%$ \\
Average of working population & $81.8 \%$ \\
Employed population & $54.9 \%$ \\
Unemployed female population & $42.6 \%$ \\
Unemployed male population & $67.8 \%$ \\
\hline
\end{tabular}

Risaralda's GDP made up COP 9.2 billion which is $1.4 \%$ of the national economy in 2012. The extractive industry, particularly mining made up COP 65,000 million of the local economy in the same year (BANREP, 2013) ${ }^{3}$. Effective multi-stakeholder collaboration processes along with economic benefits derived from mining had driven social development. Exploration and mining projects had become instrumental in helping women achieve their development aspirations.

\subsection{Nemiah Valley in Central Interior of British Columbia, Canada}

The Nemiah Valley is the western most part of the Cariboo region of BC. This area, locally referred to as Chilcotin is named after the Tsilhqot'in Indigenous people who had occupied the land prior to European settlers. The region is known for its outstanding beauty with landscapes and viewscapes that are breath taking. Coastal and glacial mountains surround the valley. Glacial waters feed the numerous pristine lakes and creeks. The area had not been subject to as much resource development activities as is the case in other parts of BC (Kunkel, 2014). This geographically isolated and remote location is the ancestral homeland of the Xeni Gwet'in people. The Xeni Gwet'in people are part of the Tsilhqot'in Tribe, a tribe indigenous to Canada. The people had lived in the Nemiah Valley for millennia; ho wever, the only access road was built in 1973 (Tsilhqot'in Nation v. British Columbia, 2006, p. 12). Prior to European settlement in BC, the Tsilhqot'in people roamed the land freely and harvested local resources to meet their daily needs. Following the British settlement in BC, the government moved the First Nations ${ }^{4}$ Indigenous people onto reserve lands (Harris, 2002). At this time, the government relocated the Xeni Gwet'in people onto eight newly created reserve communities spread out within their ancestral land with total of 1,260.50 hectares in size (Canada, 2017). The main reserve, Chilco Lake 1A, is about 554 hectares of land and is located approximately 145 miles northwest of the City of Williams Lake.

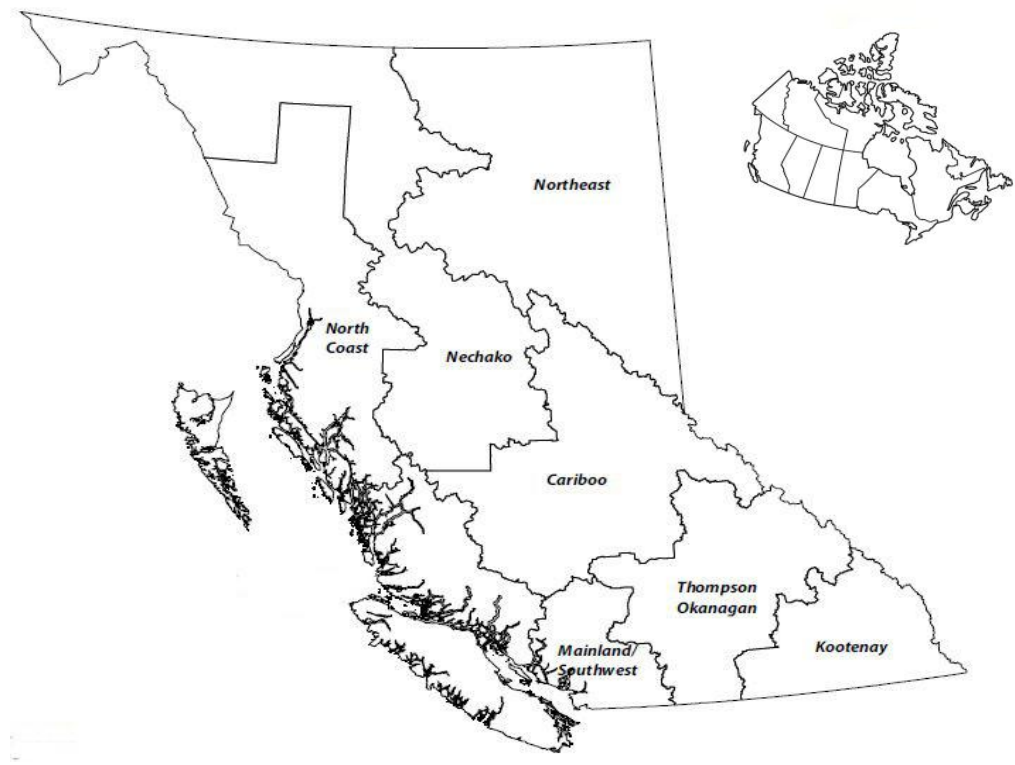

Figure 1. Map of BC Showing the Cariboo Region

The Xeni Gwet'in women rely on their lands for economic, spiritual, and cultural survival. The remoteness of their

\footnotetext{
${ }^{3} \mathrm{GDP}$ and mining production data were collected in 2012 when field research took place.

${ }^{4}$ Some First Nations groups are the original inhabitants of British Columbia.
} 
communities, the lack of economic base, and their isolation had resulted in their continued dependence on the land (Kunkel, 2014). A mining company proposed a project about $25 \mathrm{Km}$ from Chilco Lake 1A which threatened to permanently alter a watershed and to convert a fish bearing lake into a tailings pond for mine waste (Canadian Environmental Assessment Agency, 2010a). The lake containing 90,000 rainbow trout fish and its surrounding area were described as the heartland ${ }^{5}$ of the Tsilhqot'in people (Canadian Environmental Assessment Agency, 2010b, p. ii; Tsilhqot'in Nation v. British Columbia, 2007).

Table 2. Xeni Gwet'in Community Profile, 2011 Census

\begin{tabular}{lc}
\hline Xeni Gwet'in Indicator & Data \\
\hline Total population & 438 \\
Registered population living on reserve in Nemiah Valley & 185 \\
Number of female on reserve & 95 \\
Number of female aged 15 years and over & 75 \\
Median age of women & 38.9 years \\
Labour force participation rate for women & $40.0 \%$ \\
Employment rate for women & $40.0 \%$ \\
Unemployed rate for women & $0 \%$ \\
Number of women with no degrees, certificate or diploma & 35 \\
Number of women with high school diploma or equivalent only & 25 \\
Number of women with trades/apprenticeship/non-university certificate & 15 \\
\hline
\end{tabular}

The Xeni Gwet'in community had a registered population of 438 people of which 185 live on reserve lands. About 145 of the people who lived on reserve lands were aged 15 years and above with a median age of 35.7 years (Canada, 2017). Of these, $50 \%$ are women. The labour force participation rate in the community was down from $66.7 \%$ in the 2006 census to $27.6 \%$ in the 2011 census (ibid). The participation rate for women was $40.0 \%$ while that of men was $20.0 \%$. The employment rate for men was $13.3 \%$ while that of women was $40.0 \%$. There were no unemployment rate figures available (Canada, 2017). The education attainment of the people was very low. Only 45 people had completed high school or equivalent and another 25 had trade skills (Canada, 2017). Reported occupation for Xeni Gwet'in people living in Nemiah Valley are management and government with people working in manufacturing/construction, health/education and other services. Fifteen women reported working in health/education while another 15 reported working in other services (Canada, 2017). There was no census data on the number of children per household or about the income per household. There was no mining in the region despite the presence of significant amount of ore, the development of which is believed would benefit the Cariboo region (Canadian Environmental Assessment Agency, 2010a). The Xeni Gwet'in people had to weigh the promise of economic benefit versus the wealth of local ecological and Indigenous knowledge of their lands on which they had survived for millennia.

\section{Results}

The most significant finding in the Risaralda case study is the active participation of the women in the formulation of local development agendas throughout mine cycle, that is, exploration, construction, production and closure and post-closure. These women have benefited from initiatives by corporations hence able to cope with livelihood transformations. Such initiatives include development activities in agribusiness, dressmaking, jewellery, coffee production, and agriculture. These initiatives are the result of effective government-corporation partnerships and in response to requests from women.

The main finding in the Tsilhqot'in case study is that mining operations would have an adverse effect on women's livelihoods because of their dependency on the land. In the absence of development infrastructure, the Tsilhqot'in women would continue to need access to their lands to meet their daily needs.

Fashioning livelihoods of women creates value for both, the extractive industry and communities. However, stakeholders particularly the extractive industry can have difficulties in integrating community resilient which is not core to their project development. The two case studies show that the extractive industry should enhance six forms of assets in order to help women de velop more sustainable livelihoods and realize their full potential within these resource regions. These assets are income, employment, education and training, work experience and apprenticeships, infrastructure development, and upfront investment in remote communities. These findings are categorized as follows:

- Generating and managing income;

- Employment opportunities;

- Education and training;

\footnotetext{
${ }^{5}$ Heartland in this context refers to an area defined in the Tsilhqot'in court case documents as the cultural centre of the Tsilhqot'in people.
} 
- Work experience and apprenticeships;

- Infrastructure for development; and

- Upfront investment in remote communities.

\subsection{Generating and Managing Income}

Substantial transformation of community income in parts of Colombia has had an impact on women. Violent times in Risaralda diminished community opportunities to develop livelihood options other than mining. In addition, A community leader interview participant stated that the "low educational level impeded both men and women miners' [ability to] effectively administering the income they got from gold extraction" (Interview, November 2012). Interviews conducted in 2012 showed that some people did not know how to handle the monetary benefits derived from informal artisanal small scale mining neither did they realize the magnitude of the social and environmental problems triggered by poor mining practices. The effects of gender and power dynamics amongst small miners caused an increase in internal conflicts within the community. This led to some local authorities collaborating with community members and other local stakeholders to provide capacity building in the form of education to help women explore alternati ve employment and livelihood options.

The case study found that Risaralda government extended the capacity-building initiative in 2008 to include adding value to raw materials extracted in the region. This was the beginning of a successful multi-stakeholder collaboration in which "governments and civil society actors partnered to create a jewellery association - a Community-Based organization [CBO]" (Community Leader Jewellery CBO Interview, November 2012). The association became a self-sustaining local income generator for women. The arrival of multinational companies in the region further strengthened the work of the CBOs. A Canadian company operating in the region strongly supported the initiative and was keen to "promote social sustainability in other industries relevant for the community... [Similarly, the international corporation] is in a permanent dialogue with State actors to know more about community's needs and be able to assist women and local communities in increasing income" (Corporate Representative Interview, October 2012).

Collaborative approaches for enhancing economic assets for women have resulted in positive outcomes for those involved. For example, in Risaralda, a Community Leader Jewellery CBO interview participant stated that the company helped the municipality to open a plant for waste collection which has the potential for generating income for the local community (Interview, November 2012). Ongoing collaboration between companies, educational institutions, and civil society organizations has also helped women create asset-based strategies to increase local income, for example, a Community Leader Blackberry interview participant stated that universities located in the region are helping them undertake market analysis to improve cost of production and increase income (Interview, November 2012). This is very important for the people because the organization is a key stakeholder for Risaralda's agriculture sector.

Income generation in Risaralda has been driven by the need for economic diversification. Women have been able to generate income from industries other than mining. Through support from industry, community associations, and government agencies, women were able to create new employment in jewellery design and sales. The effect of this is reduced community dependency on both small and large-scale mining.

\subsection{Employment Opportunities}

Driven by strong links of reciprocity and empathy, Risaralda women more often form partnerships with other civil groups or local stakeholders to develop CBOs. The work of these CBOs in turn led to increased employment opportunities. A corporate representative interviewed stated that:

Locals have a strong sense of community organization. They own agriculture-based community associations that stimulate the local economy and foster employment. For example, they own associations for blackberry and coffee production and commercialization (Interview, October 2012).

A representative of one of the Community Leader Jewellery CBO said "at the present time we are benefiting 11 households through employment generation ... In the future it will not only be 11 but 20, 30, 50 families benefited [benefiting] from this organization" (Interview, November 2012). To date CBOs have contributed strongly to protecting and enhancing employment assets in Risaralda and collectively provide employment opportunities to 616 households. $\mathrm{CBO}$ could potentially play a stronger role in the coming years.

Creating sustainable livelihoods is a long-term process (Rakodi \& Lloyd-Jones, 2002) and involves the participation of all stakeholders. However, in the Canadian case, there are no state or industry actors working with the Tsilhqot'in people to create sustainable livelihoods. According to a community leader:

The poverty level here [is high] and the members that live here, we're all proud Tsilhqot'in, and in large part, we can, our People can live that way, because they can still depend on running down to the river and that river can provide them whatever fish is necessary. We can still go upon our lands. Whether being the mountain directly 
behind this community we've referred to as Tsi bas, we can go directly behind that mountain, we can hunt deer, we can hunt moose (Canadian Environmental Assessment Agency, 2010a, p. 3276).

However, there are some examples of mining companies that support local employment in Risaralda. A corporate representative stated that "during the exploration stage [they] are hiring local suppliers to support current drilling projects... The local community board gives [the company] potential workers' CVs and [the company] selects them through an internal process" (Interview, October 2012). Long-term strategies are required to protect and enhance livelihood assets. These strategies should encompass the mining cycle - fromexploration, through mining development, and after closure.

\subsection{Education and Training}

There are four main aspects involved in de veloping economic assets through education and training in Risaralda. Firstly, the women's needs and expectations were incorporated in the education initiatives. Secondly, community diversity was integrated in initiatives. Civil society groups are different; hence, stakeholders involved in education programs pay particular attention to these differences. For example, gender is a highly valued variable in the implementation of initiatives. Thirdly, corporations undertaking projects in the area are aware of the importance of education as an approach to development and have embraced this as an integral component of sustainable business practices. The fourth aspect is that community members have also been educated to understand the principles of socially responsible business through workshops and seminars. These aspects have helped the Risaralda women and local stakeholders to develop an approach to sustainable livelihoods tailored to their local circumstances.

Active women participation led to the creation of local initiatives for social sustainability in Risaralda. Some of these initiatives became the vehicles for enhancing several women's coping capacity and mechanisms for employment generation. One such example is the dressmaking educational programs for girls and women. Companies supported this. A community representative who participated in the focus group stated that the training would help the women get employment with either the company or educational institutions to make uniforms for workers or for students (Interview, November 2012). These initiatives are still in infancy hence their impact on communities is still unknown.

Integrating community development as part of how mining companies do business in Risaralda is helping women to positively transform economic assets and foster sustainable livelihoods. Training initiatives in place in Risaralda now cover a wide range of priority areas for women, including agriculture, jewellery making, dress making, social responsibility, human relations, and conflict resolution. The company provided the women with training in coffee making and coffee tasting and the women also requested support from companies and governments resulting in the implementation of jointly funded initiatives (Community Leaders Focus Group, October 2012). Findings indicate that this approach has positive results for communities. This was confirmed during an interview with a Community Leader Jewellery CBO member:

We have been involved in several initiatives delivered by different organizations such as Artesanias de Colombia, government-funded educational institutions and NGOs. We have experienced the benefit of these initiatives. It is reflected in the products that we design and sell (Interview, November 2012).

The main determinant of the success of training initiatives in Risaralda is the involvement of local women in the decision-making processes. This is evident in statements such as:

Women in the region identified entrepreneurship as a priority area of her [their] development aspirations. They said they wanted to be trained in dressmaking. We hired a trainer from a government-funded educational institution and allocated other resources, like dressmaking machines. (Corporate Representative Interview, October 2012)

Female leaders in Risaralda see such initiatives as opportunities to realize their full potential and build resilience to potential mining impacts. Some of the trained women become suppliers and small-business owners. While some of these women are typically wives of small-scale miners or wives of mining company employees, others are small-scale miners themselves. It is worth noting that equipping mining-dependent women with economic assets in areas other than mining is highly important in fostering social sustainability:

I am happy with the mining company's contribution. They provided us with a trainer and other resources. I am very happy; we have been able to benefit from this [program] (Community Leader Interview, November 2012).

The education initiative on sustainable business practices, led by the company, involves key areas relevant for the local community. Through this program, Risaralda women have received education in food security and family guidance (Community Representatives Focus Group, November 2012). Some women stated that education in sustainable business practices has assisted them in coping with shocks such as internal conflict. One of the respondents agreed that being exposed to this initiative has helped her and the community organization she represents "prevent conflicts within [their] association"(Community Leader Interview, November 2012). 
A combination of mining and non-mining education initiatives has served as a means to build long-term sustainability in Risaralda. The women understand that their livelihoods have to adapt to changes triggered by mining as stated by an interview participant, women are engaging with the industry but not depending on it:

We have initiatives related to mining in place. Some of them involve artisanal mining, environment, etc. However, our people cannot only rely on these initiatives as companies might leave in the future (Community Representative Interview, November 2012).

Other mining-related education explored by Risaralda women include safety, occupational health, labour risk, blasting, and drilling. This has delivered positive outcomes for women. Education has now become a primary asset that has equipped Risaralda women with the ability to gain meaningful employment and to cope with the changes triggered by mining. The Tsilhqot'in women in Nemiah Valley do not have ready access to education opportunities and continue to depend on the land to meet their daily needs.

\subsection{Work Experience and Apprenticeships}

Apprenticeship opportunities and relevant work experience are important in Risaralda. Through work experience, women have gained skills that enabled them to access jobs themselves and to foster employment opportunities for others. Women's work experience is not limited to mining but involves other areas equally important for the industry:

Local authorities administer the centres for occupations and skills. This educational institution is intended to up-skill students in bakery, electricity, and other occupations in high demand at the local and regional levels. Once students finish school, they are certified with relevant experience in their field (Government Representative Interview, November 2012).

It is government's role to contribute to building resilient livelihood assets for women. However, in Risaralda other stakeholders are also involved. The private sector and civil society actors are committed to supporting women through initiatives that integrate women's livelihoods into the mining industry. All stakeholders actively work on opportunities to enhance work experience and apprenticeship. This collaboration has been instrumental in implementing strategies hence enable Risaralda women to participate meaningfully in employment opportunities. One such example provided by a corporate representative interviewed:

We have an agreement with a higher education institution. It consists of promoting initiatives for productive chains. We supported the participation of a community leader from a CBO for blackberry production. This organization lacked expertise in this area and therefore we strongly supported his involvement in this initiative (Interview, October 2012).

The government played a key role in the development of work experience and apprenticeships programs. This strategy has helped foster the enhancement of livelihood assets for these women.

\subsection{Infrastructure for Development}

Kunkel (2014) and Franco (2014) identified infrastructure necessary for SD as human and financial capital, leadership development, adequate power supply and utilities, transportation, communication services, community buildings and housing, and access to market information. Some see the lack of tangible community infrastructure as a sign of no civilization. A Tsilhqot'in woman expressed this:

Fish Lake and Nabas area may just seem like a place in the middle of nowhere. All some people see is the rough roads, no electricity, and no civilization. To us, the Tsilhqot'in, it is our home, it is our backyard (Canadian Environmental Assessment Agency, 2010a, p. 1889).

The proposal for mine development within the Tsilhqot'in lands was seen by some as an opportunity to create local jobs. While this is true, the ability of the Tsilhqot'in women to access this would be limited because of their low educational attainment, skills level, and the lack of tangible community infrastructure.

Building and enhancing tangible community infrastructure have been a key strategy in Risaralda. For example, a government representative interviewed stated that they have been proactive in the provision of infrastructure facilities to educational institutions, women, and community members. To foster long-term improvements in livelihoods of women, the government provided school buildings for the delivery of initiatives. Furthermore, stakeholders purchase equipment for educational institutions for the delivery of these initiatives.

The development of adequate facilities has improved many women's capacity and ability to cope with mining impacts in Risaralda. Several families obtain most of their food from local women-run farms. Mining operations do threaten some existing food storage systems in Risaralda; hence, enhancing agrarian systems has become a key priority for local stakeholders. A community leader interviewed stated that one of the mining companies is helping then to design some plants for blackberry production. The community members are grateful for the support they receive. The collaboration 
has mutual benefits to the community and the company. Corporate representatives interviewed stated that they are helping community members with improvements in infrastructure and resources for blackberry plantations and are also implementing the same approach for banana plantations.

Interviews revealed that corporate support was extended to Risaralda women and the broader community by funding other education initiatives. Corporate investments include school buildings and computers. The universities also play a key role in the region, particularly in undertaking research. A community leader interviewed stated that the universities are helping them develop marketing strategies to expand local businesses (Interview, November 2012). Interviews revealed that it could be difficult for women to access universities because of their low educational attainment and financial constraints. Therefore, companies and governments strongly support the Centres for Higher Education (CERES):

We have nearly ten undergraduate programs in the centre. Ten universities offer education at CERES. This has benefited people from remote areas, as they do not have to migrate to other locations in search of education opportunities. They are provided with education in town, over the weekends (Government Representative Interview, November 2012).

Risaralda women, particularly farmers, commute on weekends to sell their local goods at the public market or to supply companies operating in the region. They also take this opportunity to participate in educational initiatives funded in partnership by governments and companies.

Corporate support for infrastructure has also been directed to non-formal education. According to the Colombian government, non-formal education aims to build work-related competences for poorly educated people (Departamento Nacional de Planeacion, 2010). Female participants in non-formal education initiatives have already experienced some of the benefits of corporate investment:

The house where we are taking [the dress-making] training is going through remodeling. The company is helping us with this. It will be much larger and in better physical condition by next year (Community Leader Interview, November 2012).

Indeed, infrastructure investment has become essential for livelihood asset transformation. Companies and other local stakeholders like governments are building community infrastructure to help women cope with the effects of mining in the long-term with the hope of creating and maintaining sustainable livelihoods.

\subsection{Upfront Investment in Remote Communities}

In Canada, Aboriginal peoples are regarded as wards of the federal government; however, there has been very little investment in community and economic infrastructures for their communities (Royal Commission on Aboriginal Peoples, 1996). The long-term effect of government policies has served to marginalize and abandon these people and their communities. Consequently, the people were forced to depend on handouts, thus creating the dependency society (Lutz, 2008; Royal Commission on Aboriginal Peoples, 1996). Amongst other things, the low education attainment, lack of access to financial capital, inadequate power supply, and government control of Indigenous lands have been barriers to the people's meaningful participation in economic activities in the region (Kunkel, 2008; Kunkel et al., 2013). The study highlighted the need for upfront investment in economic infrastructure, while this is primarily a government responsibility, the need is urgent. The price of not investing in these places will continue to limit access or increase the costs of development in the region.

Development plans made for mining projects on the Tsilhqot'in lands do not include economic infrastructure investments for the Indigenous communities. While project plans include bringing three-phase power supply to mine sites within close proximity to reserve lands, the plan bypasses communities that could do with the distribution connection. A three-phase power supply can enable remote communities to benefit economically from resource development if made available. The availability of adequate power supply can help foster the development of livelihood assets for Tsilhqot'in women and could potentially lead to the creation of economic bases for such communities.

Aboriginal communities in $\mathrm{BC}$ often state that they are not oppose to development but will embrace activities that are not detrimental to their traditional values. A community leader expressed this as:

I also want to say that we are not anti-development of the resources in Tsilhqot'in region. This is evidence by the purchase of a mill near Hansville and development of a biomass energy plant in the same area. All the First Nation communities in the Tsilhqot'in are developing economic strategies and al ways have been. Our people have the same hopes and dreams as the Canadian society in general. We want our children to receive an [sic] education, become productive members of society. Our members want jobs like everyone else. They want a colour TV, a satellite dish, a nice vehicle in the driveway, have money to go on holidays. But we will not create jobs at any cost to the environment. We will not create economic development at the expense of a sacred lake. We will not destroy 
anything valuable that relates to our teachings of our cultural and spiritual connections just for the sake of a new Dodge 4X4 (Canadian Environmental Assessment Agency, 2010a, pp. 165-166).

Unfortunately, the mill and biomass energy plant purchased by the community could not compete in the regional market due to the higher costs of operations hence had to shutdown (Kunkel, 2014, p. 201). Industry proponents can work in partnership with Aboriginal people in rural and isolated areas to help develop basic infrastructure as part of their corporate citizenship. This form of upfront reciprocity serves to build good relationships thus creating goodwill locally that can eventually lead to social license. Furthermore, the availability of physical, economic, human, and community infras tructures will enable the communities to take advantage of some of the benefits that resource development activities can provide.

\section{Discussion}

The relationship of the Indigenous Xeni Gwet'in people to the land was evident in the stories told by the Tsilhqot'in women. The testimonies of these women at the CEAA Panel Hearings in 2010 provided insights on their connections to the land and its resources. They described their seasonal activities and harvests at pertinent locations. However, what was not clear at the Hearings was how these women survive at geographically remote, often isolated locations with very little income. Interviews with some of the women revealed how they rely on local harvests for food and medicine, and for socio-cultural uses. Furthermore, they depend on wild games such as moose and deer for meat and for hide that are used for making clothing items such as vests, jackets, gloves, and moccasins. The women fish for salmon and trout and preserve these by canning, drying or smoking to last them through winter months. Some also barter canned berries, dried meat, and smoked fish for goods that are not locally available. These women sell locally made crafts to pay for school supplies and extra-curricular activities for their children. The fishing, hunting, and gathering activities, not only provide sustenance, but also are the vehicle for the transmission of their culture and language to the younger generation.

The locations of seasonal activities are archives of stories and traditions that go back millennia. The stories are transferred orally from generation to generation. Through these stories, the laws of the land are passed down to the younger generations and these are internalized at a very young age. The laws eventually become their way of life. The development of a mine at one of these locations certainly met with objections from the Tsilhqot'in people. The prospect of revenue sharing, entrepreneur development, and job creation by the mining company was not enough to convince the Federal Review Panel that the project would benefit the people, particularly the women. The lack of infrastructure such as electricity supply and the geographic remoteness of the community meant that the people would not benefit directly from whatever opportunities the mine would bring to the region. In fact, these women would lose access to their heartland and all the resources available at pertinent geographic locations. It is, therefore, important for the Tsilhqot'in women to protect areas where these activities take place for the continuity of their culture and language.

This paper identified the assets needed to transform women's livelihoods. It also highlights best practices that can be applied in other resource regions. Six main priority assets, if enhanced, would help women forge more sustainable livelihoods are employment, education, work experience/apprenticeships, income, adequate community infrastructure and upfront investment in remote communities. Although other components of human capital such as wellbeing and leadership are important, improving these six identified assets seem to be the most effective way to strengthen the ability of women to cope with mining-induced changes in resource regions.

Through direct consultation with Risaralda women, priority areas were developed to help them achieve their own development goals. These women have been successful in enhancing their livelihoods because of this bottom-up approach. The companies have embraced community-oriented and women-driven agendas; consequently, the Risaralda women have become more resilient and can participate meaningfully in employment opportunities in the region. The women also have the capacity and ability to cope with mining-induced changes. However, such approaches need to be included as an integral component of both corporate and government policies. Meaningful consultation, not merely the token provision of information, should be such that women are involved in decision-making and about matters such as priorities for asset transformation and the allocation of funds.

At the corporate level, a more women-centred approach for development has helped companies in Risaralda play a strong role in relation to capacity building initiatives. The implementation of non-mining training and education initiatives, which were women-focused, helped diversify the local economy thus making the community less mining dependent. These trainings are important in building capacity for women and in increasing their sustainable livelihood options. Mining companies funded gender-based training, for example, a Canadian company funded the dress training initiative that created value both for the company and the women themselves.

Risaralda women who are artisanal miners are participating in mining and non-mining related capacity-building initiatives. Non-mining training initiatives include finance, accounting, administration, and even literacy. Such initiatives could be expanded and made available to women in other industries. Training in jewellery design could be enhanced and replicated in other resource regions. Jewellery design not only adds value to mineral extraction but also creates alternative 
livelihoods for women. Similarly, attention paid to other sectors such as agriculture was beneficial to Risaralda. This helped women keep their traditional livelihoods. Examples from Risaralda include coffee and blackberry production training, which the private sector provided. While agriculture may not be practical for some communities due to their geographic locations, other initiative such as fish farming and aquaculture may be more appropriate. Without livelihood assets, the Tsilhqot'in women have no option but to depend on their lands. The Canadian government and industry stakeholders can work with the isolated Indigenous communities in BC to build basic infrastructure and help enhance their livelihoods through women-centred options.

In conclusion, the escalation of extractive operations has led to the perception that those can only provide short-term opportunities. In Risaralda, while mining is one option available to develop livelihood assets, education and development opportunities afforded by the industry have a longer-term impact on the livelihoods of women. The government, the extractive industry, local community, and women should be all stakeholders and participants in consultation and decision-making processes. Women-centred approached to development can serve as a valuable model for actors in other resource regions as shown in the Risaralda case. Through employment training and apprenticeship and by de veloping social and community infrastructure, Risaralda was able to enhance the livelihoods of women and strengthen economic assets thus enabling them to cope with the impacts of extractive activities. These case studies highlight important lessons drawn from two communities in the Americas. These lessons could be applied to other resource-rich regions.

\section{References}

Anderson, R. B., Dana, L. P., \& Dana, T. E. (2006). Indigenous land rights, entrepreneurship, and economic development in Canada: "Opting-in" to the global economy. Journal of World Business, 45-55. https://doi.org/10.1016/j.jwb.2005.10.005

Banco de la Republica (BANREP) (2013). Boletin Economico Regional. Eje Cafeterero: I Timestre del 2013. Retireved from http://www.banrep.gov.co/docum/Lectura_finanzas/pdf/ber_ejecafetero_tri1_2013.pdf

Bashwira, M. R., Cuvelier, J., \& Hilhorst, D. (2013). Not only a man's world: Women's involvement in artisanal mining. Resource Policy, 40(2014), 109-116. https://doi.org/10.1016/j.resourpol.2013.11.002

Buitrago Franco, I. (2013). Mining, Capacity-Building and Social License: Making the Links. The 23rd World Mining Congress. Montreal.

Canada. (2017, 03 28). First Nation profiles. Retrieved July 19, 2017, from Indigenous and Northern Affairs Development Canada: http://fnp-ppn.aandc-aadnc.gc.ca/fnp/Main/Search/SearchFN.aspx?lang=eng

Canadian Environmental Assessment Agency. (2010a). Prosperity gold-copper mine project. Ottawa, ON: Canadian Environmental Assessment Registry \#09-05-44811.

Canadian Environmental Assessment Agency. (2010b). Report of the Federal Review Panel: Prosperity gold-copper mine project, Taseko Mines Ltd., British Columbia. Ottawa, ON: Canadian Environmental Assessment Registry \#09-05-44811.

Carney, D. (2003). Sustainable Livelihoods Approaches: Progress and possibilities for change. London: Department of International Development.

Clarkson, L., Morisette, V., \& Regallet, G. (1992). Our responsibility to the seventh generation: Indigenous peoples and sustainable development. Winnipeg: International Institute for Sustainable Development.

Departamento Administrativo Nacional de Estadísticas. (2005). Perfil Risaralda. Bogota: Departamento Administrativo Nacional de Estadísticas.

Departamento Nacional de Planeacion. (2010). Plan de Desarrollo 2010-2014: Crecimiento Sostenible y Competitividad. Bogota: Departamento Nacional de Planeacion.

Dresner, S. (2008). Principles of Sustainability. London: Earthscan.

Foro Internacional de Mujeres Indigenas (International Indigenous Women's Forum). (2006). Mairin Iwanka Raya: Indigenous women stand against violence. A companion report to the United Nations Secretary General's study on violence against women. New York: United Nations.

Franco, I. (2014). Building Sustainable Communities: Enhancing Human Capital in Resource Regions. Queensland: The University of Queensland.

Harris, C. (2002). Making Native space: Colonialism, resistance, and reserves in British Columbia. Vancouver: University of British Columbia Press.

Jenkins, K. (2014). Women, mining and development: An emerging research agenda. The Extractive Industries and Society, 1(2), 329-339. https://doi.org/10.1016/j.exis.2014.08.004

Krantz, L. (2001). The sustainable livelihood approach to poverty reduction: An introduction. Swedish International 
Development Cooporation Agency. Retrieved July 24, 2017, from http://www.sida.se/globalassets/publications/import/pdf/en/the-sustainable-livelihood-approach-to-poverty-reducti on.pdf

Kunkel, T. (2008). Creating sustainable economic development for two BC First Nations communities: A rights-based approach. Prince George: University of Northern British Columbia.

Kunkel, T. (2013). Aboriginal values and the use of land and resource for traditional purposes: A presentation to the Federal Review Panel for the proposed New Prosperity Gold-Copper Mine Project. Canada: Canadian Environmental Assessment Agency. Retrieved from http://www.acee-ceaa.gc.ca/050/documents/p63928/92739E.pdf

Kunkel, T. I. (2014). Aboriginal values, sacred landscapes, and resource development in the Cariboo Chilcotin region of $B C$. Prince George: University of Northern British Columbia.

Kunkel, T. I. (2017). Aboriginal values and resource development in Native Space: Lessons from British Columbia. The Extractive Industries and Society, 4(1), 6-14. https://doi.org/10.1016/j.exis.2017.01.001

Kunkel, T. I., Halseth, G., Petticrew, E., Mills, A., Ghomshei, M., \& Ellis, R. (2013). First Nations expectations from the mining industry: Lessons from the Tsilhqot'in people. The 23rd World Mining Congress 2013. Montreal: World Mining Congress.

Lahiri-Dutt, K. (Ed.). (2013). Gendering the field: Towards sustainable livelihoods for mining communities. Canberra: The Australian National Unviersity E Press.

Lutz, J. S. (2008). Makúk: A new history of Aboriginal and White relations. Vancouver: UBC Press.

O'Faircheallaigh, C. (2013). Women's absence, women's power: Indigenous women and negotiations with mining companies in Australia and Canada. Ethnic and Racial Studies, 36(11), 1789-1809. https://doi.org/10.1080/01419870.2012.655752

Peredo, A. M., \& Chrisman, J. J. (2006). Towards a Theory of Community-Based Enterprise. Academy of Management Review, 31(2), 309-328.

Rakodi, C., \& Lloyd-Jones, T. (2002). Urban Livelihoods: A People Centred Approach to Reducing Poverty. London: Earthscan Publications.

Roy, C. K. (2004). Indigenous Women: A gender perspective. Norway: Resource Centre for the Rights of Indigenous Peoples.

Royal Commission on Aboriginal Peoples. (1996). Looking forward, looking back. In The report of the Royal Commission on Aboriginal peoples. Ottawa: Library of Parliament.

Singleton, J. R., \& Straits, B. C. (2010). Approaches to social research. (Fifth, Ed.) New York: Oxford University Press.

Statistics Canada. (2007). Cariboo, British Columbia (Code 5941). 2006 Census. Ottawa: Statistics Canada. Retrieved October 2013, from 2006 Community Profiles.

Tsilhqot'in Nation v. British Columbia, BCSC. 1700 (British Columbia Supreme Court: Reasons for judgement 2007).

Tsilhqot'in Nation v. British Columbia: Argument of the plaintiff, 1700 (BC Supreme Court 2006).

Unidad de Planeación Minero Energética. (2006). Colombia País Minero 2019. Bogota: Unidad de Planeación Minero Energética.

United Nations. (2000). Resolutions adopted by the General Assembly: United Nations millennium declaration. In R. A. Assembly (Ed.), Fifty Fifth Session. Agenda Item 60 (b). United Nations.

United Nations Development Program. (2006). Human development report. New York: United Nations. Retrieved Jul7 20, 2017, from http://mdgs.un.org/unsd/mdg/Resources/Static/Products/Progress2006/MDGReport2006.pdf

United Nations Industrial Development Organization. (2014). Mining and utilities. Vienna: Industrial Development Organization.

Wallace, S. L. (1999). Social Entrepreneurship: The Role of Social Purpose Enterprise in Facilitating Community Economic Development. Journal of Developmental Entrepreneurship, 4(2), 153-174.

\section{Copyrights}

Copyright for this article is retained by the author(s), with first publication rights granted to the journal.

This is an open-access article distributed under the terms and conditions of the Creative Commons Attribution license which permits unrestricted use, distribution, and reproduction in any medium, provided the original work is properly cited. 